\title{
PROCESS OF QUALITY IMPROVEMENT IN THE COMPANY PRODUCING BUILDING MATERIALS
}

\author{
Piotr Sygut ${ }^{1^{*}}$ \\ ${ }^{1}$ Institute of Production Engineering, Faculty of Management, Częstochowa University of Technology, \\ Al. Armii Krajowej 19B, 42-201 Czestochowa, Poland \\ * corresponding author: e-mail: sygut@zim.pcz.pl
}

\begin{abstract}
Resume
The aim of the study was to identify the problems and improve the production of cement in a ball mill in terms of technology and management associated with the use of known methods and techniques to improve quality. A detailed analysis helped to explain the process which affects the efficiency of grinding cement and which is the most common cause of disturbance and incompatibilities in the process of milling, how the production process is managed and controlled in order to obtain the required grain size, which is the main parameter influencing the quality of the manufactured product. To manage the change of the process there has been used a value stream map for analysis of the intermediate process of cement production, transport to the silos, bagging and selling. Based on the research some proposals of the process improvement have been designed that might have a chance of implementation and execution.
\end{abstract}

\author{
Article info \\ Article history: \\ Received 28 June 2013 \\ Accepted 06 September 2013 \\ Keywords: \\ cement production process, \\ the 5S method, \\ process improvement
}

\section{Scheme of cement production}

Basic components for the production of cement are: clinker, blast furnace slag, silica fly-ash and binding regulator (synthetic or natural gypsum, sand fluid).

The tanks over the mills gripper gantry are filled with basic components: clinker and binding regulator, and appropriate tank additives depending on the type of cement (a mixture of slag or ash and slag). Mineral admixtures can be divided into two main groups. The first group of these additives includes those improving the quality of the produced portland cement, to the second one belong additives which are designed to lower the cost of cement production by reducing the percentage of expensive cement clinker and replacing it with artificial or natural mineral raw materials (AHRENDS I., CIEŚLIŃSKI W. 1956).

The scheme of the cement production process with a numerical list of the equipment is shown in Fig. 1.

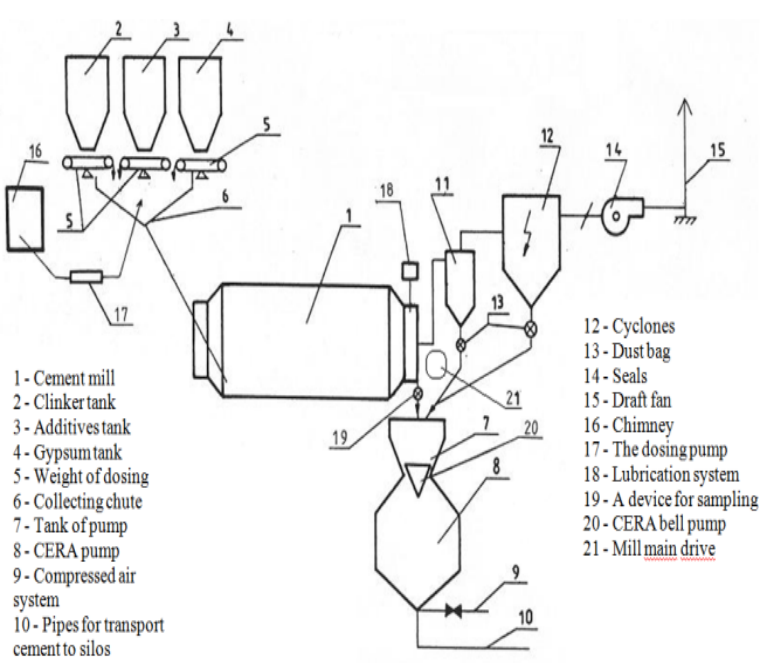

Fig. 1. Scheme the cement production process and equipment list

In the mill the components are fragmented to the appropriate grain size during the movement inside the mill; the air flow through the mill ensures the appropriate speed of the movement of the material inside the mill. Tiny grey powder 
obtained by milling the clinker is called the portland cement. The quality of the produced cement and the unit of energy consumption in the milling process are mainly determined by: the grain size of the clinker fed to the mill, the temperature and humidity of the clinker, the clinker milling ability, the degree of added additives and the degree of the cement milling (AHRENDS I., CIEŚLIŃSKI W. 1956, SYGUT P., KRYNKE M., MIELCZAREK M. 2012, BORKOWSKI S., SELEJDAK J., SALOMON SZ. 2006.).

\section{Production of cement in terms of technology}

The production process of the finished product in terms of technology is shown in Fig. 2. The presented process of production of cement concerns the same milling.

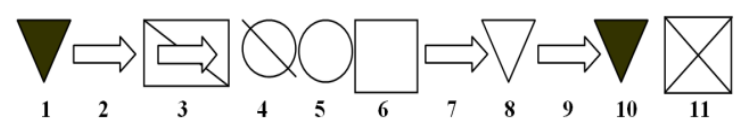

Fig. 2. The structure of cement manufacturing process in terms of technology

where:

1 - storage of raw materials (intermediates) in the hall,

2 - grab crane transport (filling baskets with raw materials),

3 - transportation of raw materials (gypsum, clinker, slag) dosing weights to the mill, quantity control (set to the mill feed),

4 - pre-milling in the first cement mill chamber,

5 - milling in the second cement mill chamber,

6 - appropriate control (determination of the relevant area, $\mathrm{CaO}$ and $\mathrm{SO}_{3}$ ),

7 - transport to the pump CERA,

8 - storage (on the line) in the pump CERA,

9 - pneumatic transport from CERA pump to cement silos,

10 - cement storage in silos,

11 - final inspection (periodic test strength).

\section{Improving working conditions in the cement plant using $5 S$ practices}

One of the many tools are Toyota Practice 5 S (BORKOWSKI S. 2004, PAWLAK W.R. 2000). The aim of $5 \mathrm{~S}$ is to introduce and maintain order and discipline in the workplace. 5S practices are one of the foundations of creating a work environment conducive to the pro-quality activities, Production Engineering Archives 1 (2013) harmonious work and continuous improvement of human relations, which translates into an effective organization.

In the cement plant under analysis what is being done to serve the purpose of ordering, simplifying and improving safety of the work environment is not seen as $5 \mathrm{~S}$ practices. However, each employee as well as visitors to the plant have noticed significant changes in recent years. The employee performs his work in a friendly and less burdensome environment for him. The operator of the process does not have red cards, but knows what tools should be in the workplace, and what should be removed. The mechanic of the repair squad after completing his work removes unnecessary parts and materials leaving good order. The most needed consumable parts are arranged on the shelf at the end of the hall and at any time can be taken in order to prevent accidents or carry out fault clearing. In addition to regular cleaning there are installed new, more efficient and energy-saving lamps, dusty equipment is sealed and dust extraction equipment is mounted on them. According to the schedule of inspections, inspection of machinery and equipment is carried out and documentation is updated. Standardization is a daily habit of activities performed in the workplace. Employees use procedures that describe the rules of conduct at the workplace. They are located in a visible place and for everyone to understand. Self-discipline is a stage of maintaining a high work discipline. In the cement plant this is seen through increased productivity, improved product quality, reduced costs, reduced levels of stocks, increased productivity and increased safety. The most important benefits that result from the use of these practices is harmonizing the activities of the organization and, consequently, the development of each employee, greater commitment and desire for innovation, improved quality and increased individual and team productivity.

In order to achieve all that, the following steps should be taken (BORKOWSKI S., SELEJDAK J., SALOMON SZ., 2006):

1. Choose a location for the implementation of practices (in the analyzed company milling plant department).

2. Photograph the place to be arranged, and after positive changes, re-take a photo. 
3. Organize the "red cards" action involving determination of necessary and unnecessary things.

4. Eliminate unnecessary things from workstations.

5. Tidy and clean out all the necessary items and equipment.

6. Place everything you need in such a way that you can quickly and easily find and apply them.

7. Mark traffic routes, racks, shelves and cabinets.

8. Assign responsibilities to each team brigade for organizing cleaning and maintaining order and cleanliness in the workplace.

9. Pay attention to cleanliness and order.

10. Use constant supervision of the development of 5S practices in order to improve discipline among employees and to develop the habit of caring for the order and its enforcement.

Preparation and carrying out of these activities take time but can be reduced if there is appropriate involvement of management and all employees of the department. Positive implementation of $5 \mathrm{~S}$ in this department will be an example and the beginning of the implementation of these practices in other departments of the cement plant. 5S method is relatively easy and cheap due to its simplicity, it is a tool for improving the organization, resulting in better understanding of the changes taking place in the company. Thus, while it may seem obvious, even with rules and good manners, $5 \mathrm{~S}$ practices should be implemented, and formally and procedurally defined.

Please note that the improvement of the production process does not end with the implementation and achievement of its objectives, but it is a continuous process (KRUCZEK M., ŻEBRUCKI Z., 2008).

\section{Conclusion}

The object of the study was portland cement fly ash-slag produced in ball mills, which are already close to 50 years of age. The main customers of the company are engaged in manufacturing and construction services as well as distributors supplying individual customers

Improving conditions in the workplace, the maintenance of order and discipline in the workplace can be achieved through the introduction of $5 \mathrm{~S}$ practices and the principle of 5W2H. Despite quite positive effects that lead to the improvement of the organization of the company in question it is advisable to introduce 5S practices and 5W2H principle in their continuous development. The most important benefits of their implementation will include harmonizing the activities of the organization, and thus the development of each employee, greater involvement, increased innovation, improved quality, and increased individual and team productivity.

\section{References}

[1] AhrendS I., CieŚLIŃSKI W. 1956. Technologia cementu. BA. Warszawa.

[2] BORKOWSKI S. 2004. Mierzenie poziomu jakości. Publisher Wyższa Szkoła Zarządzania i Marketingu w Sosnowcu. Sosnowiec.

[3] Borkowski S., Selejdak J., Salomon Sz. 2006. Efektywność eksploatacji maszyn i urządzeń. Wydawnictwo WZ P.Cz. Częstochowa.

[4] KRUCZEK M., ŻEBRUCKI Z. 2008. Wykorzystanie narzędzi lean manufacturing $w$ logistyce produkcji. Prace naukowe Politechniki Warszawskiej. Warszawa.

[5] PAWLaK W.R. 2000. Praktyki $5 S$ w przedsiębiorstwach i instytucjach, czyli dbałość o porzqdek $i$ skrzętne gospodarowanie. Wydawnictwo Informacji Zawodowej Weka. Warszawa.

[6] Sygut P., Krynke M., MielczareK M. 2012. Process Improvement in Industry of Building Materials. Chapter 5. s.56-65. Toyotarity. Improvement of Production/Service Processes. Monography. Celje. ISBN 978-961-6562-64-5. 